\title{
Education History of Meskhetian (Ahiskaian) Turks: Tsarist Russia Period
}

\author{
Gülnara GOCA MEMMEDLI ${ }^{1}$ \\ ${ }^{1}$ Faculty of Humanities and Social Sciences, Ardahan University, Turkey \\ Correspondence: Gülnara GOCA MEMMEDLI, Faculty of Humanities and Social Sciences, Ardahan University, \\ Turkey. E-mail: gulnara59@gmail.com
}

Received: September 11, 2020

Accepted: October 20, 2020

Online Published: December 26, 2020

doi:10.5539/ies.v14n1p108

URL: https://doi.org/10.5539/ies.v14n1p108

\begin{abstract}
When we talk about Meskhetian/Ahiskaian Turks, it is perceived that the Turkish community with a population of approximately 200 thousand existed in the Meskhetian/Samtskhe-Javakheti region of Georgia, who was exiled from their ancestral lands to the Central Asian countries in 1944 by the Soviet government. Due to its settled position, Ahiskaian Turkishness has been a gateway between Anatolia and the Caucasus, in other words, between the regions and civilizations, as well as the unifying bridge of Anatolian and Azerbaijani Turks. After the exile, this position expanded further, and it also assumed the role of the cultural carrier of Central Asia, Anatolia, and Azerbaijan. Today about 150 thousand Meskhetian Turks live in Kazakhstan, 100 thousand in Turkey, 100 thousand in Azerbaijan, 100 thousand in the Russian Federation, 50 thousand in Kyrgyzstan, 15 thousand in Uzbekistan, 10 thousand in the United States, 10 thousand live in Ukraine and 1,500 in Georgia. As they live in different countries, Meskhetian Turks are defined as a trans-national community. It is known that Meskhetian Turks have a rich cultural heritage. The modern type of schooling process of this community has an important historical background. In the presented article, the schools that operated before the Turks' 1944 evacuation from the historical Meskhet-Javakheti region in south-west Georgia are investigated. At the end of the 19th century, the new type of credit schools gave education in the Turkish language and opened in the villages of the Turks inhabited by the Turks in the Akhaltsikhe District in the province of Tiflis in Tsarist Russia, is being studied. In this context, the activity history of the primary schools established in the villages of Atsquri and Okam in 1881, Khertvisi in 1885, Adigeni in 1895, Oshora, Tsnisi, and Varkhani in 1897, the content of education in these schools, the contributions of reformist teachers who lit the light of enlightenment in the Akhaltsikhe cultural region, information specific to students is presented. The study's subjective sources and materials are mainly related materials in the Central Historical Archives of the National Archive of Georgia in Tbilisi.
\end{abstract}

Keywords: Meskhetian, Meskhetian Turks, education history of Ahiskaian Turks, Ahiskaian exile

\section{Introduction}

First of all, the schooling process of Meskhetian Turks, the characteristics of education in Akhaltsikhe Turkish schools, the activities of preparing Turkish teachers in Akhaltsikhe, information about the Turkish teachers and students in Akhaltsikhe draw attention. Findings of the opening dates of new types of schools called Jadid schools in Akhaltsikhe, the types of Meskhetian Turkish schools, the teaching content, the ethnic-regional factors in education, and the reformist attempts of the early teachers are of scientific value.

The findings obtained by scanning, classifying, examining, annotating the subjective archive records, printed and internet materials in accordance with qualitative research methods, and necessary results are obtained. It is argued that the exile had negative effects on the educational activities of the Meskhetian Turkish society.

The Meskhetian region, which existed with a pasha's status, under the Ottoman reign, was transferred to Russia after the 1828-1829 Ottoman-Russian war. The land was created in the Russian Empire in 1840 as an administrative unit in the status of a district within the Georgian Imereti gubernia. It was attached to the Kutaisi province in 1846 and the Tiflis province in 1867. In 1874, it was divided into two districts in Tiflis province, namely Akhaltsikhe and Akhalkalaki. There were Akhaltsikhe and Akhalkalaki districts in the Democratic Republic of Georgia since 1918 and in the Georgian Soviet Socialist Republic between 1921-1930. While raions-districts were established in 1830, Akhaltsikhe, Adigeni, Aspindza, Akhalkalaki, and Ninotsminda districts were established in this region. Today, these lands are defined as Samtskhe-Javakheti province, with which the city 
of Akhaltsikhe is the center. Based on the statistical population data of 1885, it is seen that a total of 31,012 people in 150 villages in the district of Akhaltsikhe and a total of 4,163 people in approximately 30 villages in the district of Akhalkalaki were inhabited collectively (Tiflis Governorate, 1886, pp. 2-29).

In the statistical records of 1917, it was determined that 15.040 Turks lived in the Akhaltsikhe district and 3.619 Turks in the Akhalkalaki district (Statistical data of Georgia, 1921, p. 23).

\section{Material and Resource}

The history of education, as a field of science, undertakes an important and honorable task for our present and future, with the mission to bring forward the experiences, traditions, and pedagogy principles of education. Based on such a purpose, researching the educational and schooling heritage of the Meskhetian Turks in Georgia appears as a current justification.

Akhaltsikhe has been accepted as the name of this region in Turkish. Akhaltsikhe was the name of a principality, a pasha, a district, a township, and today it is the name of a district, region, and district city center. It is known that the Atabeks state was established in the vicinity in the Middle Ages. The Ottoman Empire conquered Akhaltsikhe and Akhalkalaki sections by the Childir War in 1578 and connected to Childir province, the northeastern region of Anatolia was celebrated as the northeastern region of Anatolia for 250 years, the Russian Empire took over the region in 1828, the region was in the Georgian Imereti Gubernia until 1847, and it was in the status of a district in Kutaisi Gubernia between 1847-1867, in Tiflis Governorate between 1867-1921, joined the Georgian Soviet Socialist Republic in 1921, and the Turks were exiled from there on 15 November 1944 (Chichinadze, 1906; Kirzioglu, 1970; Kojoridze, 1987; Lortkipanidze, 1994; Kalkan, 1998; Zeyrek, 2001; Hajili, 2009; Beridze, 2013; Aydingün, 2015; Çinar, 2015; http://www.ahiska.org.tr).

Due to the region's geographical location, the coexistence of various religions, languages, and cultures, Akhaltsikhe and its surroundings have been a multicultural region in terms of religion, language, and ethnicity. Since ancient times, these places have been known as one of the centers of science, culture, and education. The history of modern type schools is also remarkable here.

In Akhaltsikhe, we can classify the modern Turkish education process in three stages: The tsarist Russia period (until 1917); The period of the Democratic Republic of Georgia (1918-1921), the Soviet period (1921-1944).

In the study process, the related materials of the Caucasus Education Department and Tiflis Governorate Schools inspectors in the Central Historical Archive of the National Archive of Georgia, and explanatory articles about the Meskhetian region in Russian encyclopedias and statistical journals in Tiflis were examined.

\section{Method}

Based on the characteristic features of the study materials, mostly historical-pedagogical analysis technique was followed. Empirical (experimental) analysis, synthesis, induction, and deduction methods were also applied during the classification, examination, and evaluation of the data in terms of pedagogy experience. Since the subject covers the historical background, the qualitative-historical research method has also been applied.

\section{Results and Discussion}

\subsection{New Style Schooling Process}

From the 30s of the 19th centuries, district schools were established in three cities in Georgia Tiflis, Kutais, and Meskhetian. In the report of 1845, it was reported that the students in the Meskhetian district normal-modern school wrote and read well in Turkish and translated them well into the Russian language. Turkish children were also educated in this school, and Omar Efendi Alioglu became a Turkish language teacher (Pashaev, 2012, p. 37).

In line with the implementation of the "Public Schools Regulation" in Tsarist Russia since the 1870s (Gagua, 1982, p. 38), normal village schools or Russian-Tatar, in other words, Russian-Turkish schools, have been established for the South Caucasian Turks since this period. Such schools were opened in Qizilhajili, Sarvan, Arukhly villages of Borchaly district and in Qarajala village of Telavi district of Tiflis Governorate (Gocaeva, 2003, p. 23).

During the years 1896-1898, famous educator, journalist Omar Faig Nemanzadeh attempted to open a Turkish style school in Atsquri village and submitted a petition to the director of education in Tiflis under the name of the villagers and was responded as: "You should send the students to the shkola if necessary, there will be no Turkish school" (Nemanzadeh, 2006, p. 322). As O. F. Nemanzadeh underlines imaginatively, in Tiflis, "most of the educated people I met were government servants, cowards, religious, and those who were in place of Mirza Fetali's Akhundzade were black Russian queues far from national civilization and science" (Nemanzadeh, 2006, p. 323).

Nemanzadeh wrote the following in his article titled "Letter from Ahalsihe" in the newspaper "Tercuman" in 1900: 
"We neither have a new school nor an old one! Our society is merciful. They make a great deal of the vocational school, and he has Armenian, Jewish, and Georgian students to be taught ... By this calculation, although there is a school for 40 thousand people, there are one tavern and two coffeehouses per twenty houses. Our education is at such a level that there is only one Muslim from us in Transcaucasian Teachers Seminary in city Gori, four hours away. Our statesmen and gentlemen, who will guide the society, are not few, but they have very little support for education and the nation. For this reason, our mosques are ruined, our schools are devastated, and our situation is bad" (Nemanzadeh, 2006, pp. 21-22; Çitil, 2013, p. 14; http://www.ahiska.org.tr/?p=3248).

Therefore, attempts to open a mother-tongue school in the Meskhetian region, where Turks were inhabited, should be considered as a matter of virtue.

Regarding regional schools, the head of the Akhaltsikhe district in 1885 presented a report to the governor of Tiflis by saying that: "Exceptions with the schools of the Society for the Spreading of Christianity in the Caucasus and the schools opened in the villages of Tadriz, Adigeni, and Ude in the Atsquri town, the situation of the remaining schools, including Muslim schools within the mosques, in the account of the mosques is not good", and the mullahs who teach lessons in these schools are less literate, they do not have any education, and on this occasion, education in schools is carried out with traditional methods (National Archive of Georgia 17/1/2289, pp. 14b, 15).

In this period, the number of "Russian-Tatar", in other words, Russian-Turkish schools in Georgia is expressed as 1 school in 1877, 14 schools in 1898, 15 schools in 1908, 18 schools in 1913, 21 schools in 1916 (Pashaev, 2012, p. 104).

Towards the end of the 19th century, generally, seven Turkish schools existed in the district of Meskhetian in Tiflis Governorate of Tsarist Russia.

We were able to identify the villages where primary schools were opened in the district as follows: Atsquri in 1881, Okami in 1881, Adigeni in 1895, Khertvisi in 1885, Oshora in 1897, Tsnisi in 1897, Varkhani in 1897.

Two of these schools were in Adigeni district - Adigeni, Varkhani, two in Akhaltsikhe district - Atsquri, Tsnisi, one in Aspindza district - Oshora, two in Akhalkalaki district - Khertvisi and Okam.

\subsection{New Style Schools}

Atsquri school: The opening date is November is 8, 1881. Atsquri was the largest village with Turks in the region. It is on the Kura river bank, between the town of Borjomi and the city of Akhaltsikhe. It is known for its Atsquri castle. Archive document regarding this school's opening: "Akhaltsikhe district chief, 9 November 1881, No 7945, Akhaltsikhe city. Caucasus Education Administration trustee. Report. I would like to thank you with Akhaltsikhe honor that a new village school was opened by me in Atsquri and Tadriz villages on 8 November this year with the participation of the mediator of the Meskhetian branch" (National Archive of Georgia 422/1/1373, pp. 2-3). It was the second Turkish school after the school opened in 1876 in the Qizilhajili village of Borchaly district in Tiflis Governorate. Atsquri village is on the Akhaltsikhe - Borjomi highway. In 1870, 773 people in 129 families (Materials for the depiction, 1870, p. 357) in the Atsquri village of Akhaltsikhe district, 1,706 people in 279 families in 1885, as well as 5,546 people in 737 families (Statistical information 1893) in the Azgur district were inhabited. At different times, Abel Bairamov, Dursun Agalioglu, Abdul Hairov, Huseyn Efendiev, son of Molla Ali Ibrahimoglu, Mirza Huseyn Hasanzade became the principal-teacher in this school, which was opened in Atsquri village and served the local villages. Omar Faig Nemanzadeh and later Molla Abnur Kadiroglu had taught Sharia and Turkish language lessons. The students were mostly boys. It is stated from the magazine "Molla Nasraddin": "Akhalkalak people looked to the Atsquri people and bestowed two hundred kopecks on Atsquri's community school. As we have heard, God will send a gift from the fruit of the oleander tree of Hell to those who try to destroy the school by distributing stamps of the community schools to the peasants" (Molla Nasraddin, 1907/24). In the 1920s, Mustaiddin Tulava, Hairiye Nurueva, Osman Mammadov, Sherif Manafzade, and others taught at the school.

Okami school: The year of its opening is 1881. According to statistics, 653 people (Tiflis Governorate, 1886, p. 24) Qarapapaq-Terekeme Turks lived in Okami, the most populous village villages where Turks lived in the district of Akhalkalaki. In 1903, 76 households were registered here. The founding teacher of the school was Haji Abdur Ibrahimoglu, who is a resident of Okam. Abdullah Bey Abashidze is also mentioned among his primary teachers. The school could not operate for a long time due to the lack of teachers.

Khertvisi school: Its opening year is 1885. In this village, which was connected to the district of Baraleti, the district of Akhalkalaki was inhabited by Imirhasan Qarapapaqs. In 1870, 1,159 Turkish people were registered in the village (Materials for the depiction, 1870, p. 361). Aslan Muradov, a graduate of the seminary, was the founder of the school. The activity of the school was mostly linked to the activity of the local resident Mammadaga 
Mustafaev. Rufat Efendi Vachnadze, Solomon Ustuev, and others also worked here.

Adigeni school: Its opening year is 1895 . At times, the school was faced with the problem of teachers and students. Varkhani school: Its opening year is 1897 . The village has become the second largest village in the area after Atsquri. In 1885, 488 people in 85 families and 4,110 people in 599 families in the Varkhani community were inhabited in this village, which was connected to the Adigeni district of the county (Statistical information, 1893). Educated teacher, Mirza Habibullah Alizade from Fakhraly village of Borchaly district, played an important role in the establishment of the school. During the Soviet regime, Emrullah Vaysalzade, Hamid Mammadov, Enver Odabashov, and others also worked here.

Oshora school: The opening is year 1897. Meskhetian district was connected to the Idumala community. The village belonged to Meskhetian district, the Idumala community,743 people in 83 families in the village of Zemo-upper Oshora, and 581 people in 56 families in the village of Kvemo-lower Oshora (Statistical information, 1893) inhabited here in 1885. The school in the village stopped its activities for a short time. Mammad Miragaev, Mammad Dedeev, Ahmed Miragaev, Aliasker Mahmudoglu, and others were among its teachers.

Tsnisi school: The opening year is 1897. In 1885, 293 people in 36 families in the village and 5.114 people in 608 families in Klde community, which this village belonged to, settled in this village (Statistical information, 1893). The village was a town center in the district of Meskhetian. Halai Sultan Muradov, who graduated from the seminary, founded the school. Sarvar Ibrahimov served in the development of the school.

\subsection{School Types}

The schools of Atsquri, Okami, Adigeni, Khertvisi, Oshora, Tsnisi, Varkhani, which existed in the region, operated in the type of village primary school. These schools included two-year education and included Russian language and Russian law lessons and Turkish language and Sharia lessons in their curriculum.

Concerning this type of school, Omar Faig Nemanzadeh used the definition of "Usul-i Jadid school" (Nemanzadeh, 2006, pp. 21-22). Ikram Çinar emphasized that: "The primary school providing contemporary scientific education is a Jadid school opened in Atsquri in 1881. Meskhetians were raising their own intellectuals from the second half of the 19th century under the influence of the Jadidism operation" (Ahiskaian Turks, 2019, p. 193).

As we know, the word Jadid is an Arabic word and means "new", and the term "Usuli Jadid schools" means "new-style schools", ie secular schools, are considered. We can use the definition of "Usuli Jadid school" regarding the new, secular type schools opened in the district of Akhaltsikhe towards the end of the 19th century.

\subsection{Textbooks}

The need for textbooks, supplementary teaching literature, and equipment of Turkish schools in Georgia, brought from Baku from Azerbaijan and published in Azerbaijani Turkish in Tiflis, provided a certain extent. The Turkish schools of the region consisted of a single classroom, and the use of the book "New Alphabet", which was arranged and published by the well-known pedagogue Mahmud Bey Mahmudbeyov, was used. In this book, which is written in an enlightened language and qualifies as a national textbook, letters are taught on the basis of pictures and the spelling of words is explained.

Turkish grammar was taught in Georgian Turkish schools by using the books such as "Kindergarten", "First year", "Second year", "Turkish alphabet", "Homeland language", "Full alphabet" (National Archive of Georgia 1935/1/745, pp. 52-54).

" - "Vatan Dili". The "Homeland language" textbook was published in Tiflis in 1888 for the benefit of Turkish offspring in line with the principle of conducting first-year education in the mother tongue of every people in Caucasian primary schools. The first part of this book, which was arranged for teaching with the Savti method, was arranged or the first year and the second part for the second-year students.

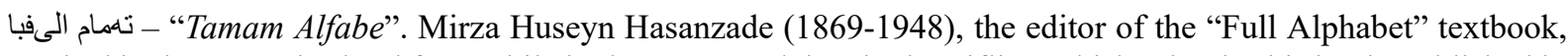
worked in the Atsquri school for a while in the 1890s and then in the Tiflis Turkish school. This book, published in Tiflis in 1912, was intended for the first grade of primary schools and arranged in a Savti style. In the book, vowel sounds were added to the Arabic alphabet, and some consonant sounds were made, and bonds were simplified. Numerous pictures, small-scale texts, stories, and poems are given.

\subsection{Teachers}

We can divide the Turkish entrepreneurial intellectuals who taught in the Meskhetian region into two groups:

- Those who were born in Akhaltsikhe and graduated from the teaching seminar and worked as a teacher in 
their hometown;

- $\quad$ Those who came from outside of Meskhetia and worked as teachers in the region's Turkish villages.

Seminary is called colleges that prepare male teachers for secondary schools in Tsarist Russia. It corresponds to the Ottoman darulmuallim. The South Caucasus Seminary in Gori, Georgia, has been the most typical pedagogical institution that prepares trained teacher staff for primary schools south of the Caucasus. The said seminar was established in 1876, and in 1879 the Azerbaijan-Turkish branch started its activities with the seminary.

Aslan Muradov, a graduate of Meskhetian Seminary, played an active role in the Mahammad Mustafaev Khertvisi school's activities, the Halai Sultan Muradov Tsnisi school, and the Nadir Muradov Akhaltsikhe city gymnasium (National Archive of Georgia 427/45, p. 44; 1935/1/1751, pp. 1-3). Seminary graduates had theoretical knowledge and practical exercises in didactic and methodical terms, and on this occasion, they conducted the lectures methodically properly and with good intention Abdul Hairov, who was from Atsquri village, one of the local teachers of Akhaltsikhe and worked as a teacher and a director at the Atsquri school between 1887 and 1890 , completed the Simferepol teaching seminary in Crimea (Report 1888, p. 274). Rufat Efendi Vachnadze, who taught the Russian language, Georgian language, and Sharia at the Khertvisi school since 1885, graduated from the "Omariye" Turkish school (National Archive of Georgia 427/45, p. 44; Report 1895, p. 36). Omar Faig Nemanzadeh studied in Darüşşafaka in Istanbul. He was not given a school principal because he did not graduate from a Russian school, and he taught Sharia and Turkish lessons in the new type of school (Nemanzadeh, 2006, pp. 38-39).

In addition to these, we can show Abel Bairamov, Mirza Habib Alizade, Huseyn Efendiev, Mirza Huseyn Hasanzade, and others who came from Georgia's Tiflis, Borchaly, Karaiazy Azerbaijan's Qazakh, Tovuz, Zaqatala regions and contributed to education in the villages of Akhaltsikhe region (National Archive of Georgia 422/1/1208, pp. 1-2, 422/1/4707, p. 7; Report 1893, p. 347; 1895, p. 36; Gocaeva, 2003, pp. 26-27, 116-117; Memmedli, 2018, p. 253).

In the Turkish schools of the country, the need for the teaching of Sharia as an elective course was foreseen at the request of the people, and it became clear that it was necessary to benefit from the knowledge and experience of religious education. In this respect, Omar Efendi Alioglu, Mirza Ahmedoglu, Dursun Agalioglu in Akhaltsikhe district school, Molla Ali Halai Ibrahimoğlu, Osman Efendiev, Molla Abnur Qadiroglu, Memmed Zeki Dursunzade in Atsquri school, Haji Abdur Ibrahimoglu in Khertvisi and Okam, Bachet Arifoglu at Oshora school, Idris Kochaliev at Varkhani school, Ibrahim Ishikoglu at Tsnisi school, Mammad Rashidzade in Adigeni school had taught Sharia and Turkish language (National Archive of Georgia 422/2/396, p. 1; 422/2/427, p. 1; 427/45, pp 47-48; Hajili, 2009, p. 108; Report 1888, p. 274; 1893, p. 347; 1895, p. 36).

Huseyn Efendiev, Muhammad Mustafaev, Mirza Habib Alizade, Mirza Huseyn Hasanzade, Halai Sultan Muradov, and others, who were the school directors in the region, were graduates of the South Caucasus teacher seminary.

The teachers were both educators and cultural carriers in the villages.

\subsection{Student Activity}

We can determine the student quotas of schools from the pre-1921 information in accordance with archive documents. 
Table 1. Showing student activity in schools in Meskhetia region:

\begin{tabular}{|c|c|c|c|c|c|c|c|}
\hline Years & Atsquri & Okami & Khertvisi & Adigeni & Varkhani & Oshora & Tsnisi \\
\hline 1887 & 23 & 35 & 67 & & & & \\
\hline 1888 & & & 94 & & & & \\
\hline 1889 & 23 & 15 & 88 & & & & \\
\hline 1890 & 25 & 23 & 84 & & & & \\
\hline 1891 & 31 & 22 & 92 & & & & \\
\hline 1893 & 15 & 36 & 80 & & & & \\
\hline 1894 & 22 & & 70 & & & & \\
\hline 1895 & 32 & 9 & 34 & 15 & & & \\
\hline 1896 & 28 & 56 & 40 & 30 & & & \\
\hline 1897 & & & 15 & 63 & 31 & 12 & 10 \\
\hline 1898 & 52 & 38 & 52 & 65 & & 40 & \\
\hline 1899 & 27 & 29 & 36 & 27 & 30 & 40 & 27 \\
\hline 1900 & 28 & 18 & 9 & 45 & 30 & 32 & 39 \\
\hline 1901 & 11 & 16 & 71 & 22 & 25 & & 25 \\
\hline 1902 & 32 & 20 & 26 & 22 & 23 & 27 & 23 \\
\hline 1903 & 31 & 24 & 92 & 27 & 15 & 23 & 30 \\
\hline 1905 & 38 & & & & & 8 & 23 \\
\hline
\end{tabular}

(National Archive of Georgia 427/45, p. 5; Report 1888, pp. 274-275, 1889, pp. 28, 65, 1891, pp. 28, 71, 1894, pp. $33,79,1895$, p. 36,1896 , p. 40,1898 , p. 44,1899 , p. 46 ...)

In terms of student quota, Khertvisi primary school has been successful. In some years the number of students in the school has reached 100. In the primary schools of Okami, Adigeni, Varkhani, and Oshora, only boys have always continued their education. In Atsquri, Khertvisi and Tsnisi primary schools, girls as well as boys were encouraged to attend school.

\section{Conclusion}

The first modern educational schools of Meskhetian Turks are Atsquri, Okami primary schools, which were founded in 1881. They were followed by Khertvisi village primary school in 1885 and then by Adigeni, Varkhani, Oshora and Tsnisi primary schools towards the end of the century.

In this process, there was no distinction between Ahiskaian and Borchalian, and the graduates of the seminary from the Borchaly region played an active role in the first steps of education in the vicinity of Meskhetian.

Between 1918-1921, the network of Turkish-language schools was expanded in the Democratic Republic of Georgia on the grounds of nationalization of education, and on the occasion of the transition to education in mother tongue in accordance with the constitution, Turkish language education was carried out in Turkish language primary schools in Akhaltsikhe and Akhalkalaki districts, and the Turkish language was given the status of the main course.

Since education was established on the basis of nationality within the framework of the democratic system, the Turks in Georgia were also educated in their native language, and they learned Turkish, Turkish literature, and Azerbaijani literature in more detail. The Turkish language and other lessons, including literature, history, geography, and Sharia, were carried out based on the curriculum organized with the Georgian Turks National Council's consent.

In 1921-1944, teaching courses were also active in Turkish pedagogical techniqums - teacher vocational schools in the village of Benara in Adigeni district, in the village of Toloshi in Aspindza district in the city of Akhaltsikhe.

Following the Soviet occupation of Georgia and the Meskhetian region within its borders, the followings occurred in the process of development of Turkish education in the region:

Schools have been established in all Turkish inhabited villages of the region,

Akhaltsikhe, Adigeni, Akhalkalaki pedagogical techniqums - vocational education schools were opened.

In the case of Turkish schools operating in the Meskhetian region, factual findings are primarily important for Meskhetian knowledge.

On the morning of November 15, 1944, 125 thousand local Turks from 220 villages of the five districts of 
Georgia's Meskhetian region, in other words, Samtskhe-Javakheti province, were forced into migration. During the evacuation of the Meskhetian/Ahiskaian Turks from Georgia to the Central Asian geography with the Soviet Union administration's ideological aim, not only people but also ancient history, unique culture, rich folklore, literature, and enlightening educational traditions were subjected to forced migration.

\section{References}

Ahiskaian Turks. (2019). International Turkish Communities Information Festival Proceedings. Bursa: Turkish Hearths spring.

Aydingün, A. (2015). The past, present and future of the Meskhetian Turks. Yeni Türkiye, 78/8, 223-233.

Beridze, M. (2013). The origins and present of the Muslim Meskhes. Akhaltsihe: University publications.

Chichinadze, Z. E. (1906). The Islamization of Meskhet Javakheti. Tbilisi: Ideal publications.

Çinar, I. (2015). Atabeks Land: geocultural approach. Istanbul: IQ publications.

Çitil, R. (2013). The printing life of Omar Faig Nemanzadeh. Bizim Ahiska, 31, 13-15.

Gagua, V. V. (1982). On the history of primary education in pre-revolutionary Georgia. Tbilisi: Ganatleba bublications.

Gocaeva, G. N. (2003). The education of Azerbaijanis in the Democratic Republic of Georgia (1818-1821) (Doctoral dissertation, Baku: State University).

Hajili, A. A. (2009). The knowledge of Meskhetian Turks homeland. Istanbul: Akhaltsikhe Promotion Agency publications.

Kalkan, M. (1998). Origin and historical development of Meskhetian Turks. Bilig, 7, 160-171.

Kirzioglu, M. F. (1970). “Meskhetian region and Turkishness”. Türk Kültürü, 87, 35-38.

Kojoridze, D. (1987). Samtskhe Javakheti, the past and the contemporary phase. Tbilisi.

Lortkipanidze, V. (1994). Samtskhe Javakheti (demographic development problems) in the 19-20 centuries. Tbilisi.

Materials for the depiction. (1870). Materials for the Depiction of the Tiflis Governorate. Tbilisi (Archive of the National Library of Georgia, R2/353.486/3).

Molla Nasraddin. (1907). Humor magazine. Tbilisi, 24.

Nemanzadeh, O. F. (2006). Selected works. Baku: Şerq Qerb publications.

Pashaev, E. H., Bairamov, N. E., \& Gocaeva, G. N. (2012). Azerbaijani schools in Georgia. Tbilisi: Tbiliselebi publications.

Report. (1888-1902). Report on the state of educational institutions of the Caucasian Education Department. Tbilisi (Archive of the National of Georgia, T984, T1891).

Statistical data of Georgia. (1921). Tbilisi.

Statistical information. (1893). Statistical information about the population of the South Caucasus State taken from the 1886 family lists. Tbilisi. (Archive of the National Library of Georgia, R70.806/3, R5.546/4, R17.087.4).

Tiflis Governorate. (1886). Tiflis Governorate Statistics Committee Studies. Tbilisi (Archive of the National Library of Georgia, 00502017).

Zeyrek, Y. (2001). Ahiska region and Ahiskaian Turks. Ankara: Positive publications.

\section{Copyrights}

Copyright for this article is retained by the author(s), with first publication rights granted to the journal.

This is an open-access article distributed under the terms and conditions of the Creative Commons Attribution license (http://creativecommons.org/licenses/by/4.0/). 